\title{
PENGARUH MOTIVASI DAN PENGALAMAN KERJA TERHADAP PRODUKTIVITAS KERJA KARYAWAN PT. COMINDO MITRA SULAWESI CABANG PALOPO
}

\author{
Salju ${ }^{1}$, Muhammad Lukman ${ }^{2}$ \\ Email : ${ }^{1}$ )saljusanuddin68@gmail.com, ${ }^{2}$ )muhammadlukman@gmail.com
}

${ }^{1,2}$ )Program studi Manajemen, Sekolah Tinggi Ilmu Ekonomi Muhammadiyah Palopo

\begin{abstract}
Abstrak
Penelitian ini bertujuan untuk mengetahui pengaruh motivasi dan pengalaman kerja terhadap produktivitas kerja karyawan pada PT. Comindo Mitra Sulawesi Cabang Palopo. Metode yang digunakan adalah metode analisis regresi linier berganda. Data yang digunakan adalah data primer dan data sekunder yang dihasilkan dari penelitian lapangan dan studi kepustakaan. Hasil analisis regresi berganda penelitian ini membuktikan bahwa motivasi dan pengalaman kerja berpengaruh positif namun tidak signifikan terhadap produktivitas kerja karyawan pada PT. Comindo Mitra Sulawesi Cabang Palopo. Nilai koefisiensi korelasi pada output SPSS sebesar 0,919. Dengan hasil analisis yang telah dilakukan, maka peneliti menyimpulkan bahwa terbukti terdapat hubungan yang sangat kuat antara motivasi dan pengalaman terhadap produktivitas kerja karyawan pada PT. Comindo Mitra Sulawesi Cabang Palopo. Secara parsial hasil analisis menunjukkan motivasi berpengaruh positif terhadap produktivitas kerja karyawan. Pengalaman kerja berpengaruh positif terhadap produktivitas kerja karyawan.
\end{abstract}

\section{Kata kunci : Motivasi, Pengalaman Kerja dan Produktivitas Kerja Karyawan}

\section{PENDAHULUAN}

\section{A. Latar belakang masalah}

Kualitas sumber daya manusia sebagai tenaga kerja merupakan modal dasar dalam masa pembangunan. Tenaga kerja yang berkualitas akan menghasilkan suatu hasil kerja yang optimal sesuai dengan target kerjanya. Manusia sebagai tenaga kerja atau karyawan merupakan sumber daya yang penting bagi perusahaan, karena mereka mempunyai bakat, tenaga dan kreativitas yang sangat di butuhkan oleh perusahaan untuk mencapai tujuannya.

Motivasi kerja merupakan hal yang berperan penting dalam meningkatkan suatu produktivitas kerja, karena orang yang mempunyai motivasi kerja yang tinggi akan berusaha dengan sekuat tenaga agar pekerjaanya dapat berhasil dengan baik dan membentuk suatu peningkatan produktivitas kerja (Hasibuan, 2007:219).

Berbagai pandangan yang dapat membantu kita memahami bagaimana motivasi mempengaruhi produktivitas kerja. Pada dasarnya, teori-teori motivasi dapat dibedakan menjadi 3 (tiga) macam kelompok yaitu: Pertama teori isi (content theory) yang menjelaskan tentang "apa" motivasi itu, kedua teori proses (process theory) yang menjelaskan tentang "bagaimana" motivasi itu, ketiga teori prilaku (reinforcement theory) yang mejelaskan tentang perilaku seseorang dalam kaitan dengan motivasi (Ranupandojo dan Husnan, 2000:325).

Pengembangan konsep-konsep motivasi, telah berkembang teori-teori motivasi yang dapat memberikan penjelasan mengenai motivasi kerja para anggota organisasi, mulai dari teori dini motivasi seperti teori hierarki kebutuhan dari moslow, teori X dan Y oleh Mc Gregor, teori motivasi model dua faktor oleh Herzberg, teori ERG dari Al Defer, teori kebutuhan dari Mc Clelland yang kesemuanya bertitik tolak dari kebutuhan individu. Peneliti akan menjelaskan beberapa dari teori tersebut (Siagian, 2013:289).

Motivasi dan pengalaman kerja yang baik dapat juga menunjang keberhasilan suatu perusahaan dalam mencapai tujuannya. Sebab melalui adanya dua faktor tersebut akan menciptakan tingkat produktivitas kerja sehingga menunjang keberhasilan perusahaan. Sebaliknya jika tingkat produktivitas kerja menurun akan menghambat perusahaan tersebut dalam mencapai tujuannya.

Pengalaman kerja (senioritas) yaitu promosi yang didasarkan pada lamanya bekerja seorang karyawan (Hasibuan 2010:109). Pengalaman kerja sebagai pertimbangan promosi seseorang dalam perusahaan dan menjadi prioritas utama untuk penjenjangan karir karyawan. Dengan pengalaman seseorang dapat mengembangkan kemampuannya sehingga tetap betah bekerja pada perusahaan dengan harapan suatu waktu ia 
akan dipromosikan. Kelemahannya adalah seorang karyawan yang kemampuannya sangat terbatas, tetapi karena sudah lama bekerja tetap dipromosikan.

Pengalaman yang didapat seseorang akan lebih cakap dan terampil serta mampu melaksanakan tugas pekerjaannya. Dengan latihan berulang-ulang akan meperkuat dan meningkatkan pengetahuan dan kemampuan seseorang. Bagi karyawan yang telah melalui proses penjenjangan secara sistematis dalam bekerja maka akan menambah pengalaman kerja, sehingga karyawan tersebut mampu menyelesaikan masalah-masalah yang dihadapinya dalam proses bekerja. Kemampuan seseorang dapat diukur dari masa kerja dan tingkat pengetahuan serta keterampilan yang di milikinya.

Menurut (Handoko, 2001) ada beberapa faktor yang mempengaruhi pengalaman kerja adalah sebagi berikut:

1. Latar belakang pribadi, mencakup, pendidikan, kursus, latihan bekerja dan menunjukan apa yang telah dilakukan seseorang diwaktu yang lalu.

2. Bakat dan minat, untuk memperkirakan kapasitas dan kemampuan menjawab seseorang.

3. Sikap dan kebutuhan, untuk meramalkan tanggung jawab dan wewenang seseorang.

4. Kemampuan analisis dan manipulatif, untuk mempelajari kemampuan penilaian dan penganalisaan.

5. Keterampilan dan kemampuan teknik, untuk menilai kemampuan dalam pelaksaan aspek-aspek teknik pekerja

Pengalaman kerja seseorang akan dapat mengembangkan kemampuannya sehingga karyawan tetap betah bekerja pada perusahaan dengan harapan suatu waktu ia akan dipromosikan. Pengalaman kerja pada pekerjaan yang sejenis perlu mendapatkan pertimbangan dalam penempatan tenaga kerja. Makin lama tenaga kerja tersebut bekerja, makin banyak pengalaman yang dimilikinya, sebaliknya makin singkat masa kerja seseorang, makin sedikit pengalama kerja yang diperoleh.

Produktivitas mencakup sikap mental karyawan yang memandang ke depan secara optimis dengan memegang keyakinan diri bahwa kehidupan hari ini adalah lebih dari hari kemarin dan hari esok adalah lebih baik hari ini. Produktivitas adalah perbandingan antara hasil dengan masukan, peningkatan produktivitas hanya dimungkinkan oleh adanya peningkatan efesiensi (waktu, bahan dan tenaga) serta sistem kerja, teknik produksi dan adanya peningkatan keterampilan dari tenaga kerja (Hasibuan, 2005:231).

Menurut (Muchdarsyah, 2001:23) menyebutkan bahwa faktor-faktor yang dapat berpengaruh terhadap produktivitas kerja adalah sebagai berikut :

1. Pendidikan.

Manusia yang memiliki pendidikan lebih tinggi pada umumnya mempunyai wawasan yang lebih luas terutama penghayatan akan arti pentingnya produktivitas dapat mendorong pegawai yang bersangkutan melakukan tindakan yang produktif. Pendidikan, baik formal maupun informal, akan mendorong karyawan bertindak produktif.
2. Disiplin.

Disiplin kerja yaitu, sikap patuh, taat, dan sadar pada peraturan lembaga atau organisasi. Disiplin kerja dapat membuat pekerjaan cepat terselesaikan.

3. Motivasi.

Motivasi Yaitu dorongan kehendak yang mempengaruhi perilaku karyawan meningkatkan produktivitas kerjanya. Apabila karyawan mendapatkan motivasi, maka akan menimbulkan psikologis untuk meningkatkan dedikasi serta memanfaatan potensi yang dimiliki untuk meningkatkan produktivitas kerja.

4. Keterampilan dan pengalaman.

Apabila pegawai semakin terampil dan berpengalaman, maka akan lebih mampu bekerja serta menggunakan fasilitas kerja dengan baik. Oleh karena itu tujuan perusahaan dapat di capai.

5. Seni serta ilmu manajemen.

Manajemen adalah faktor produksi dan sumberdaya ekonomi, sedangkan seni adalah pengetahuan manajemen yang memberikan kemungkinan peningkatan produktivitas. Manajemen termasuk perbaikan melalui penerapan teknologi dan pemamfaatan pengetahuan yang memerlukan pendidikan dan penelitian.

6. Modal.

Modal merupakan landasan gerak suatu perusahaan, karena dengan modal perusahaan dapat menyediakan peralatan bagi manusia yaitu membantu melakukan pekerjaan dalam meningkatkan produktivitas kerja. Fasilitas yang memadai akan membuat semangat kerja bertambah secara tidak langsung produktivitas dapat meningkat.

Produktifitas merupakan perbandingan antara hasil yang dicapai (keluaran) dengan keseluruhan sumber daya (masukan) yang dipergunakan per satuan waktu, definisi kerja ini mengandung cara atau metode pengukuran, walaupun secara teori dapat dilakukan secara tetapi secara praktek sukar dilaksanakan, terutama karena sumber daya masukan yang dipergunakan umumnya terdiri dari banyak macam dan di proporsi yang berbeda.

Dari uraian tersebut di atas, peneliti merasa tertarik melakukan penelitian terkait dengan "Pengaruh motivasi dan pengalaman kerja terhadap produktivitas karyawan PT.Comindo Mitra Sulawesi Cabang Palopo".

\section{B. Tujuan penelitian}

1. Untuk mengetahui sejauhmana motivasi berpengaruh terhadap produktivitas karyawan pada PT. Comindo Mitra Sulawesi Cabang Palopo.

2. Untuk mengetahui sejauh mana pengalaman kerja berpengaruh terhadap produktivitas karyawan PT. Comindo Mitra Sulawesi Cabang Palopo. 


\section{Manfaat Penelitian}

Manfaat yang akan di berikan dengan adanya penelitian ini adalah sebagai berikut:

1. Manfaat teoritis. Penelitian ini diharapkan dapat memberi masukan yang bermanfaat bagi perusahaan, yaitu mampu meningkatkan motivasi yang berkaitan di berikan berkaitan dengan produktivitas.

2. Manfaat Praktis. Penelitian ini di harapkan akan memperluas wawasan untuk mengimplementasikan pengetahuan teoritis yang telah di peroleh penulis khususnya dalam bidang manajemen sumber daya manusia di dalam kondisi nyata.

\section{METODE PENELITIAN}

\section{A. Jenis penelitian}

Jenis penelitian ini adalah penelitian kuantitatif yang diklasifikasikan kedalam penelitian dasar (basic research), sedangkan berdasarkan tingkat kealamiahan, metode penelitian ini dapat dikelompokkan menjadi metode penelitian survey (Sugiyono, 2012:4).

\section{B. Fokus penelitian}

Fokus penelitian ini adalah peneliti ingin mengatahui keterkaitan antara disiplin motivasi dan pengalaman kerja dalam hubungannya dengan produktivitas karyawan dengan studi kasus pada PT. Comindo Mitra Sulawesi Cabang Palopo.

\section{Defenisi operasional}

Motivasi adalah serangkaian sikap dan nilai-nilai yang mempengaruhi individu untuk mencapai hal yang spesifik sesuai dengan tujuan yang ditetapkan oleh PT. Comindo Mitra Sulawesi Cabang Palopo.

Pengalaman kerja adalah kemampuan yang dimiliki seseorang mengenai obyek tertentu dan dalam kurun waktu yang ditentukan oleh PT. Comindo Mitra Sulawesi Cabang Palopo (minimal enam bulan).

Produktivitas karyawan adalah perbandingan antara keluaran (output) dengan masukan (input) dari karyawan dalam suatu periode tertentu pada PT. Comindo Mitra Sulawesi Cabang Palopo.

\section{Indikator}

1. Motivasi

Menurut Usman (2006) indikator-indikator motivasi di antaranya sebagai berikut:
a. Prestasi
b. Kerjasama
c. Tanggung jawab
d. Kegairahan bekerja
e. Hubungan harmonis

2. Pengalaman kerja

Indikator pengalaman kerja menurut Foster (2001) menyatakan sebagai berikut :
a. Masa kerja
b. Tingkat pengetahuan dan keterampilan
c. Penguasaan terhadap pekerjaan dan peralatan

3. Produktivitas

Menurut Sutrisno (2011) menyatakan bahwa indikator produktivitas adalah :
a. Kemampuan
b. Hasil yang dicapai
c. Semangat kerja
d. Pengembangan diri
e. Mutu
f. Efisiensi

\section{Teknik pengumpulan data}

Teknik pengumpulan data yang digunakan pada penelitian ini adalah penelitian langsung dengan menggunakan kuisioner yang dibagikan kepada seluruh responden dengan sampel sebanyak 25 dari total karyawan PT. Comindo Mitra Sulawesi Cabang Palopo sebanyak 51 orang.

\section{E. Analisis data}

\section{Uji Validitas Reliabilitas}

Uji validitas merupakan alat yang digunakan untuk mengukur seberapa tepat alat ukur yang digunakan untuk melakukan fungsi ukurannya. Uji validitas pada instrument ini menggunakan bantuan program SPSS. Suatu instrument dilakukan valid apabila instrument pembentuk variable memiliki korelasi dengan skor masing-masing variable $>0,25$.

Berdasarkan Uji validitas yang telah dilakukan, maka dapat disimpulkan bahwa semua item yang digunakan untuk mengetahui pengaruh motivasi dan pengalaman kerja serta produktivitas dinyatakan valid. 


\section{HASIL DAN PEMBAHASAN}

Table 1. Uji Validitas

\begin{tabular}{|c|c|c|c|c|}
\hline Variabel & Item & R Hitung & R Tabel & Keterangan \\
\hline \multirow[t]{3}{*}{ Motivasi } & $\mathrm{X} 1.1$ & 0,845 & 0,264 & Valid \\
\hline & $\mathrm{X} 1.2$ & 0,588 & 0,264 & Valid \\
\hline & $\mathrm{X} 1.3$ & 0,791 & 0,264 & Valid \\
\hline \multirow[t]{3}{*}{ Pengalaman Kerja } & $\mathrm{X} 2.1$ & 0,549 & 0,264 & Valid \\
\hline & $\mathrm{X} 2.2$ & 0,786 & 0,264 & Valid \\
\hline & $\mathrm{X} 2.3$ & 0,871 & 0,264 & Valid \\
\hline \multirow[t]{3}{*}{ Produktivitas kerja } & Y.1 & 0,775 & 0,264 & Valid \\
\hline & Y.2 & 0,739 & 0,264 & Valid \\
\hline & Y.3 & 0,789 & 0,264 & Valid \\
\hline
\end{tabular}

Sumber: hasil olah data primer, 2018

Uji reliabilitas bertujuan untuk mengetahui apakah alat pengumpul data pada dasarnya menunjukkan tingkat ketepatan, keakuratan dan kestabilan atau konsistensi alat tersebut dalam mengungkapkan gejala-gejala tertentu dari sekelompok individu, walaupun dilakukan pada waktu yang berbeda. Dalam penentuan tingkat reliabilitas suatu instrumen penelitian, secara umum keandalan dalam kisaran > 0,60 s/d 0,80 baik, serta dalam kisaran > 0,80 s/d 1.00 dianggap sangat baik. (Santoso, 2001).
Untuk menentukan reliabilitas terhadap butir-butir pernyataan variable dilakukan pengujian dengan komputer program SPSS 20.1 for windows 7 dengan rumus Cronbach's Alpha. Berdasarkan tingkat reliabilitas, hasil uji koefisien reliabilitas (r Alpha) terhadap ketiga instrumen variabel yang diuji dapat dirangkum pada tabel :

Tabel 2. Uji Reliabilitas

\begin{tabular}{|l|l|l|l|}
\hline No & Variabel & Cronbach alpha & Keterangan \\
\hline 1 & Motivasi & 0,607 & Baik \\
\hline 2 & Pengalaman kerja & 0,658 & Baik \\
\hline 3 & Produktivitas kerja & 0,653 & Baik \\
\hline
\end{tabular}

Sumber: hasil olah data primer, 2018

Berdasarkan tabel rangkuman hasil uji reliabilitas diatas, nilai alpha cronbach untuk stres kerja adalah 0.607 , kepuasan kerja 0.658, dan kinerja karyawan 0.653 . Hal ini berarti bahwa pernyataan untuk seluruh item pernyataan adalah baik untuk motivasi, pengalaman kerja dan produktivitas kerja karyawan. 


\section{Analisis regresi linear berganda}

Untuk mengetahui sejauh mana pengaruh motivasi $\left(\mathrm{X}_{1}\right)$, pengalaman kerja $\left(\mathrm{X}_{2}\right)$ terhadap produktivitas karyawan (Y) digunakanlah model regresi linear berganda. Hasil perhitungan menggunakan aplikasi SPSS 2.1, sebagai berikut :

Tabel 3. Regresi linear berganda

Coefficients $^{\mathrm{a}}$

\begin{tabular}{|ll|l|l|l|l|l|}
\hline \multicolumn{2}{|l|}{ Model } & \multicolumn{2}{|l|}{$\begin{array}{l}\text { Unstandardized } \\
\text { Coefficients }\end{array}$} & $\begin{array}{l}\text { Standardized } \\
\text { Coefficients }\end{array}$ & T & Sig. \\
\cline { 3 - 6 } & B & Std. Error & Beta & \\
\hline & (Constant) & 9,981 & 2,015 & & 4,953 &, 000 \\
1 &, 234 &, 122 &, 267 & 1,923 &, 060 \\
& X1 &, 037 &, 095 &, 055 &, 395 &, 695 \\
\hline
\end{tabular}

Sumber: hasil olah data primer, 2018

Tabel menunjukan perhitungan regresi, nilai konstanta yang diperoleh adalah 9,981 dan koefisien regresi motivasi sebesar 0,234 dan pengalaman kerja sebesar 0,37. Sehingga persamaan regresi yang diperoleh adalah sebagai berikut :

$$
\begin{aligned}
& \mathrm{Y}=9,981+0,234 \mathrm{X}_{1}+0,37 \mathrm{X}_{2} \\
& \mathrm{Y}=\text { Motivasi } \\
& \mathrm{X}_{1}=\text { Pengalaman Kerja } \\
& \mathrm{X}_{2}=\text { Produktivitas Kerja }
\end{aligned}
$$

Persamaan regresi di atas dapat dijelaskan sebagai berikut:

a. Jika motivasi dan pengalaman kerja belum ada maka produktivitas kerja karyawan pada PT.Comindo Mitra Sulawesi Cabang Palopo adalah sebesar 9,981.

b. Kofesien regresi motivasi $\left(\mathrm{X}_{1}\right)$ sebesar 0,234 ini bermakna bahwa apabila motivasi mengalami perubahan sebesar 0,234, maka akan berpengaruh terhadap produktivitas kerja sebesar satu satuan sebesar 0,234 dengan anggapan pengalaman kerja $\left(\mathrm{X}_{2}\right)$ tetap.

c. Kofesien regresi pengalaman kerja $\left(\mathrm{X}_{2}\right)$ sebesar 0,37 ini bermakna bahwa apabila pengalaman kerja mengalami perubahan sebesar 0,37 maka akan berpengaruh terhadap produktivitas kerja sebesar satu satuan 0,37 sebesar 9,981 dengan anggapan motivasi $\left(\mathrm{X}_{1}\right)$ tetap.

\section{Analisis Koefisien Determinasi $\left(\mathbf{R}^{2}\right)$}

Analisis koefisien determinasi digunakan untuk mengetahui seberapa besar persentase pengaruh variabel motivasi dan pengalaman kerja secara bersama sama terhadap kinerja karyawan. Adapun hasil analisis koefisien determinasi dapat kita lihat pada tabel berikut ini :
Tabel 4. R Square $\left(\mathbf{R}^{2}\right)$ Model Summary

\begin{tabular}{|l|l|l|l|l|}
\hline Model & $\mathrm{R}$ & $\begin{array}{l}\mathrm{R} \\
\text { Square }\end{array}$ & $\begin{array}{l}\text { Adjusted } \\
\mathrm{R} \text { Square }\end{array}$ & $\begin{array}{l}\text { Std. Error } \\
\text { of the } \\
\text { Estimate }\end{array}$ \\
\hline 1 &, $273^{\mathrm{a}}$ &, 075 &, 036 & 1,12220 \\
\hline
\end{tabular}

Sumber: hasil olah data primer, 2018

Tabel menunjukan nilai $\mathrm{R}$ yang diperoleh sebesar 0,273 artinya hubungan antara Variabel independen dengan dependen sekitar 27,3\%. Sementara nilai adjustied $R$ square $\left(R^{2}\right)$ yang diperoleh sebesar 0,036 atau 3,6\%, artinya 3,6\% variabel kinerja dapat dijelaskan oleh variabel Motivasi dan Pengalaman kerja. Sedangkan sisanya $(100 \%-3,6 \%=96,4 \%)$ dijelaskan oleh sebab atau variabel yang belum dimasukan ke dalam model. 
Tabel 5. ANOVA ${ }^{\mathrm{a}}$

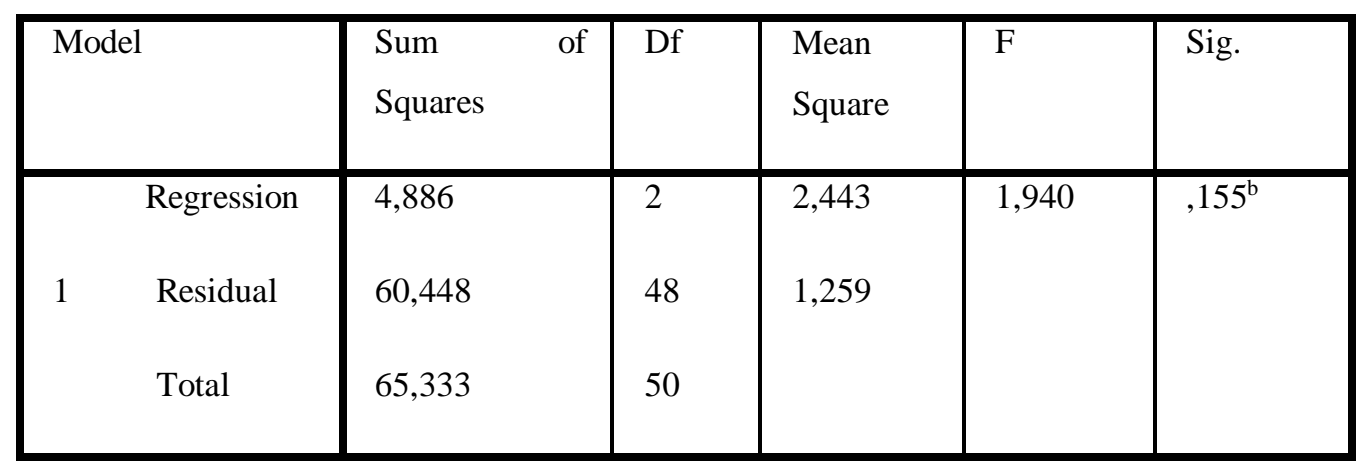

Sumber: hasil olah data primer, 2018

Tabel menunjukan hasil uji ANOVA atau F test diperoleh nilai hitung sebesar 1,940 dengan probabilitas 0,155 . Oleh karena nilai probablitas lebih besar dari 0,05, maka model regresi dapat digunakan untuk memprediksi produktivitas atau dapat dikatakan bahwa variabel independen (motivasi dan pengalaman kerja) secara bersama sama tidak berpengaruh terhadap variabel dependen (produktivitas kerja).

\section{Hasil Uji Hipotesis}

Uji statistik t pada dasarnya digunakan untuk melihat pengaruh variabel independen terhadap variabel dependen secara parsial. Pengaruh variabel motivasi dan pengalaman kerja terhadap produktivitas kerja pada PT. Comindo Mitra Sulawesi Cabang Palopo secara parsial/individual, hasil uji hipotesis yang diperoleh adalah sebagai berikut:

a. Nilai siqnifikan motivasi sebesar 0,60 nilai ini lebih besar dari 0,05 yang berarti motivasi berpengaruh positif namun tidak signifikan terhadap produktivitas kerja karyawan. Dengan demikian $\mathrm{H}_{1}$ yang menyatakan bahwa motivasi berpengaruh siqnifikan terhadap produktivitas ditolak.

b. Nilai siqnifikan sebesar 0,695 nilai ini lebih besar dari 0,05 yang berarti motivasi berpengaruh positif namun tidak signifikan terhadap produktivitas kerja karyawan. Dengan demikian $\mathrm{H}_{2}$ yang menyatakan bahwa pengalaman kerja berpengaruh siqnifikan terhadap produktivitas kerja karyawan ditolak.

\section{HASIL PENELITIAN}

\section{A. Pengaruh Motivasi Kerja Terhadap Produktivitas Kerja Karyawan}

Hasil pengujian hipotesis (H1) terbukti bahwa analisis regresi menunjukan nilai kofesien varibel motivasi sebesar 0,234 dan nilai siqnifikan 0,60 nilai ini lebih besar dari 0,05 yang berarti motivasi berpengaruh positif namun tidak signifikan terhadap produktivitas kerja karyawan PT. Comindo Mitra Sulawesi Cabang Palopo. Hasil perhitungan dengan pengujian secara statistik bernilai positif bermakna bahwa apabila perusahaan meningkat motivasi dalam bentuk material (pemberian bonus, insentif dan kenaikan tunjangan lainnya) maupun non material (menciptakan suasana yang kondusif dilingkungan kerja), maka akan meningkatkan produktivitas kerja karyawan. Sedangkan nilai tidak signifikan bermakna bahwa sampel yang dijadikan responden dianggap kurang meyakinkan dapat mewakili seluruh populasi yang ada, walaupun ada pengaruh antara variabel motivasi terhadap produktivitas kerja karyawan di PT. Comindo Mitra Sulawesi Cabang Palopo. Untuk penelitian yang terkait antara motivasi dan produktivitas, seharusnya menggunakan sampel lebih banyak dan bahkan lebih meyakinkan apabila seluruh populasi dijadikan responden.

\section{B. Pengaruh Pengalaman Kerja Terhadap Produktivitas Kerja Karyawan}

Hasil pengujian hipotesis $(\mathrm{H} 2)$ terbukti bahwa analisis regresi menunjukan nilai kofesien varibel pengalaman kerja sebesar 0,37 dan nilai siqnifikaan 0,695 nilai ini lebih besar dari 0,05 yang berarti pengalaman kerja berpengaruh positif namun tidak signifikan terhadap produktivitas karyawan. Hasil pengujian secara statistik membuktikan bahwa motivasi berpengaruh positif terhadap produktivitas kerja karyawan, hal tersebut dapat bermakna bahwa apabila seseorang mempunyai pengalaman kerja yang lebih lama, maka dianggap mempunyai produktivitas lebih tinggi apabila dibandingkan dengan seseorang yang belum mempunyai pengalaman kerja, walaupun dianggap tetap mempunyai pengaruh terhadap perusahaan. Sedangkan nilai tidak signifikan bermakna bahwa sampel yang dijadikan responden dianggap kurang meyakinkan dapat mewakili seluruh populasi yang ada, walaupun ada pengaruh antara variabel pengalaman kerja terhadap produktivitas kerja karyawan di PT. Comindo Mitra Sulawesi Cabang Palopo. Untuk penelitian yang terkait antara pengalaman kerja dan produktivitas, seharusnya menggunakan sampel 
lebih banyak dan bahkan lebih meyakinkan apabila seluruh populasi dijadikan responden.

\section{PENUTUP}

\section{A. Simpulan}

Penelitian ini akan disimpulkan hasil penelian yang yang dianggap bermanfaat bagi PT Comindo Mitra Sulawesi Cabang Palopo. Penelitian ini mencoba meneliti mengenai pengaruh motivasi dan pengalaman kerja karyawan pada PT. Comindo Mitra Sulawesi Cabang Palopo. Berdasarkan uraian dan penjelasan yang telah di kemukakan pada bab sebelumnya, maka dapat ditarik kesimpulan sebagai berikut:

1. Secara persial motivasi dan pengalaman kerja berpengaruh positif dan tidak siqnifikan terhadap produktivitas kerja karyawan pada PT. Comindo Mitra Sulawesi Cabang Palopo.

2. Variable motivasi dan pengalaman kerja, kofesien regresi bertanda positif $(+)$ menandakan hubungan searah, dengan kata lain motivasi dan pengalaman kerja akan meningkatkan produktivitas kerja karyawan pada PT. Comindo Mitra Sulawesi Cabang Palopo.

\section{B. Saran}

Untuk mencapai tujuan pada PT. Comindo Mitra Sulawesi Cabang Palopo, maka peningkatan produktivitas kerja karyawan merupakan hal yang mutlak dilaksanakan. Barkaitan dengan hal tersebut, maka beberapa saran yang ingin disampaikan sebagai berikut:

1. Disarankan kepada perusahaan untuk selalu memberikan peluang berupa kenaikan gaji, memfasilitasi karyawan untuk mempererat hubungan sesama rekan kerja, menciptakan lingkungan kerja yang relatif lebih nyaman bagi karyawan, mengembangkan keterampilan dan kemampuan pada karyawan agar karyawan lebih meningkatkan kinerjanya dan menguntungkan bagi perusahaan.

2. Disarankan kepada perusahaan untuk selalu memperhatikan absensi karyawannya, meningkatkan pelatihan, mempertahankan kesejahteraan yang baik, melakukan motivasi yang berkala dan memberikan kesempatan yang lebih luas untuk promosi pada karyawannya agar karyawan lebih meningkatkan kinerjanya dan menguntungkan bagi perusahaan.

3. Diharapkan penelitian selanjutnya dapat mengkaji lebih dalam tentang pengaruh motivasi dan pengalaman kerja yang pada penelitian ini berpengaruh terhadap produktivitas kerja pada PT.Comindo Mtra Sulawesi Cabang Palopo agar diperoleh gambaran yang lebih lengkap sehingga diharapkan hasil penelitian yang akan datang lebih sempurna dari penelitian ini.

\section{DAFTAR PUSTAKA}

Hasibuan, Malayu. 2001. Manajemen Sumber Daya Manusia:Pengertian Dasar,Pengertian, dan Masalah. Jakarta: PT. Toko Gunung Agung.

Hasibuan, Malayu.. 2005. Manajemen Sumber Daya Manusia. (Edisi Revisi). Jakarta:Bumi Aksara.

Sugiyono. 2010. Metode Penelitian Bisnis. Cetakan ke 15. Bandung : CV. Alfabeta.

Sutrisno, Edy. 2011. Manajemen Sumber Daya Manusia. Jakarta: Prenada Media Group.

Usman, H. 2006. Manajemen Teori-Praktik dan Riset Pendidikan. Jakarta :Bumi Aksara

Ghozali, Imam. 2013. Aplikasi Analisis Multivariate dengan Program IBM SPSS 21 Update PLS Regresi. Semarang: Badan Penerbit - Universitas Diponegoro

Handoko, T. Hani. 2001, Manajemen Personalia Dan Sumber Daya Manusia. Edisi 2. Cetakan Kedelapan Belas. Yogyakarta: BPFE.

Hasibuan, Malayu S.P. 2005.Produktivitas. Bumi Aksara, Jakarta

Moh As'ad, 1978, Psikologi Industri, Liberty, Yogyakarta

Handoko, T. Hani. 2000. Konsep Motivasi, Cetakan Kedelapan belas, BPFE Yogyakarta, Yogyakarta.

Hasibuan.2010, Pengalaman Kerja.Bumi Aksar. Jakarta.

Foster, Bill. 2001. Pembinaan untuk Peningkatan Kinerja Karyawan. PPM . Jakarta

Hasibuan, Malayu. 2001. Manajemen Sumber Daya Manusia:Pengertian Dasar,Pengertian, dan Masalah. Jakarta: PT. Toko Gunung Agung.

Hasibuan, Malayu.. 2010. Manajemen Sumber Daya Manusia. (Edisi Revisi). Jakarta:Bumi Aksara.

Sugiyono. 2010. Metode Penelitian Bisnis. Cetakan ke 15.Bandung: CV. Alfabeta.

Sutrisno, Edy. 2011. Manajemen Sumber Daya Manusia. Jakarta: Prenada Media Group.

Sugiyono, 2002. Statistika Untuk Penelitian. CV. Alfabeta, Bandung.

Hasibuan, Malayu S.P., 2000. Manajemen Sumber Daya Manusia. PT. Bumi Aksara, Jakarta.

Siagian, P. 2013, “ Manajemen Sumber Daya Manusia”. Bumi Aksara. Jakarta.

Budiono, H. 2004. Pengantar Manajemen. Cetakan Kedua. Graha Ilmu. Yogyakarta.

Hasibuan, M, S, P. 2003. Manajeman Sumber Daya Manusia. Edisi Revisi. Bumi Aksara. Jakarta.

Malayu S.P. Hasibuan, 2000, Manajemen Sumber Daya Manusia, Yogyakarta, Liberty. 